\title{
SNX31 wt Allele
}

National Cancer Institute

\section{Source}

National Cancer Institute. SNX31 wt Allele. NCI Thesaurus. Code C102907.

Human SNX31 wild-type allele is located in the vicinity of $8 q 22.3$ and is approximately 91 $\mathrm{kb}$ in length. This allele, which encodes sorting nexin-31 protein, plays a role in intracellular transport. 